\title{
Water Resources Conflict Management of Nyabarongo River and Kagera River Watershed in Africa
}

\author{
Telesphore Habiyakare ${ }^{1,2}$, Nianqing Zhou ${ }^{{ }^{*}}$ \\ ${ }^{1}$ Department of Hydraulic Engineering, Tongji University, Shanghai, China \\ ${ }^{2}$ College of Science and Technology, University of Rwanda, Kigali, Rwanda \\ Email: t.habiyakare@yahoo.com, nq.zhou@tongji.edu.cn
}

Received 9 July 2015; accepted 7 August 2015; published 10 August 2015

Copyright $@ 2015$ by authors and Scientific Research Publishing Inc.

This work is licensed under the Creative Commons Attribution International License (CC BY). http://creativecommons.org/licenses/by/4.0/

(c) ()

\begin{abstract}
In the process of exploiting and using water resources of river basin, the benefit conflict problems among upper and lower river districts and among different departments restrict to sustainable exploiting and using water resources of river basin. In this paper, the water resources conflict management of Nyabarongo River and Kagera River watershed is studied. The Nyabarongo is a major river in Rwanda, begins in Nyungwe Forest, and flows up to the north-western part of the country, then down through the center to the south-east, eventually forming the main tributary of the Kagera River watershed, the main affluent of Lake Victoria, which drains into the Nile River. The basin is shared among 11 riparian states. This trans-boundary character of the Nile presents a great challenge of water conflicts; national interests have historically been promoted at the expense of regional interests. The framework of this paper is as follows: the water resources bulletin is firstly described, and then the cooperation and regional conflicts are discussed; finally a sustainable framework for governing the water resources is proposed to meet water management in riparian states.
\end{abstract}

\section{Keywords}

Water Management, Water Conflicts, Nile River, Kagera Watershed

\section{Introduction}

Rwanda is a mountainous area with an altitude ranging between $900 \mathrm{~m}$ and $4507 \mathrm{~m}$, and has a tropical temperate

\footnotetext{
${ }^{*}$ Corresponding author.
}

How to cite this paper: Habiyakare, T. and Zhou, N.Q. (2015) Water Resources Conflict Management of Nyabarongo River and Kagera River Watershed in Africa. Journal of Water Resource and Protection, 7, 889-896. 
climate due to its high altitude. The average annual temperature ranges between $16^{\circ} \mathrm{C}$ and $20^{\circ} \mathrm{C}$, without significant variation. Rainfall is abundant although it presents some irregularities. The average arable surface area available is about 0.60 ha per household use. This causes overexploitation of available land, which is often accompanied by agricultural malpractices with disastrous consequences on land resources and on environment in general [1]. The degradation of the natural environment is particularly linked with soil erosion that affects the important portion of agricultural land. Generic impacts of erosion are numerous: increasing sedimentation on land cultivated downhill from eroded plots; loss of soil fertility by leaching arable lands; risk of destruction of crops and sand banks which are particularly high in marshlands and valleys; risks of landslides [2].

Rwanda possesses a relatively big quantity of surface water and underground water: rivers, lakes and marshlands occupy a surface area of 211,000 ha, which is about $8 \%$ of the national territory (lakes: 128,000 ha, rivers: 7260 ha and marshlands: 77,000 ha). The outflow of the renewable underground resource is estimated at $66 \mathrm{~m}^{3} / \mathrm{s}$, out of which $9 \mathrm{~m}^{3} / \mathrm{s}$ is produced by 22,000 known sources. In general, too little information is available especially on underground water aquifers [3]. Rwanda counted 11,689,696 inhabitants with a surface area of 26,338 $\mathrm{km}^{2}$ during August 2012 national census with an annual growth rate of 3\%, which means: the population density of 419.8 inhabitants per $\mathrm{km}^{2}$ and which is one of the highest densities on African continent. The gross domestic product (GDP) of Rwanda is dominated by the agricultural sector [4]. This has a great impact on water use in general, especially in Kagera watershed.

\section{Methods}

The aim of writing this paper is to review information about Kagera watershed, as well as proper management of the users. The paper will first concentrate on introduction and brief background of Kagera Basin, then go on the situation of Kagera watershed and its boundaries. This paper will also focus on Regional River management, water resources bulletins across Nyabarongo and Kagera River including water use and demand projection, Cooperation and Regional water conflicts in Nile Basin. Finally this study will propose the mechanism for sustainable water resources management of the Kagera watershed and the commitment of the Nile riparian countries to foster co-operation and pursue jointly the sustainable development and management of Nile water resources for the benefit of all.

\section{The Study Area Description and Regional River Management}

\subsection{Geographical Location}

Located in the Great Lakes Region of Africa, the Kagera River Basin covers an area between the immense Lakes of Victoria, Tanganyika and Kivu. The Kagera River Basin is shared by Rwanda, Burundi, Uganda and Tanzania and flow to The Lake Victoria and drains to Nile River as shown in Figure 1.

The Kagera River drains a basin area of $59,800 \mathrm{~km}^{2}$ distributed among the countries of Burundi (22\%), Rwanda (33\%), Tanzania (35\%) and Uganda (10\%) [5] as shown in Table 1.

\subsection{Kagera Sub-Catchments}

The Kagera River has its main sources in north-eastern side of Congo Nile Divide in Burundi (Ruvubu) and in the western highlands of Rwanda (Nyabarongo). It stretches about $800 \mathrm{~km}$ from its remotest source in the Virunga region in Rwanda to its outlet on the western shores of Lake Victoria in Uganda. The main tributaries of the Kagera River are the Ruvubu River gathering the waters from Burundi and the Nyabarongo River flowing from Rwanda.

\subsubsection{The Ruvubu River}

The Ruvubu River rises in the southern part of the Congo-Nile Divide in the tropical rain forest of Burundi in the province of Kayanza. Its head lies in the Kibira National Park at about 2000 metres a.s.l. and traverses about $350 \mathrm{~km}$ to its confluence with the Kagera River on the border between Rwanda and Tanzania [6].

\subsubsection{The Nyabarongo River}

The Nyabarongo River (Figure 2) flows over $300 \mathrm{~km}$ from its source in western Rwanda southwards to its outlet to Lake Rweru in south-eastern Rwanda along the border with Burundi. Its main tributary is Kanyaru River 


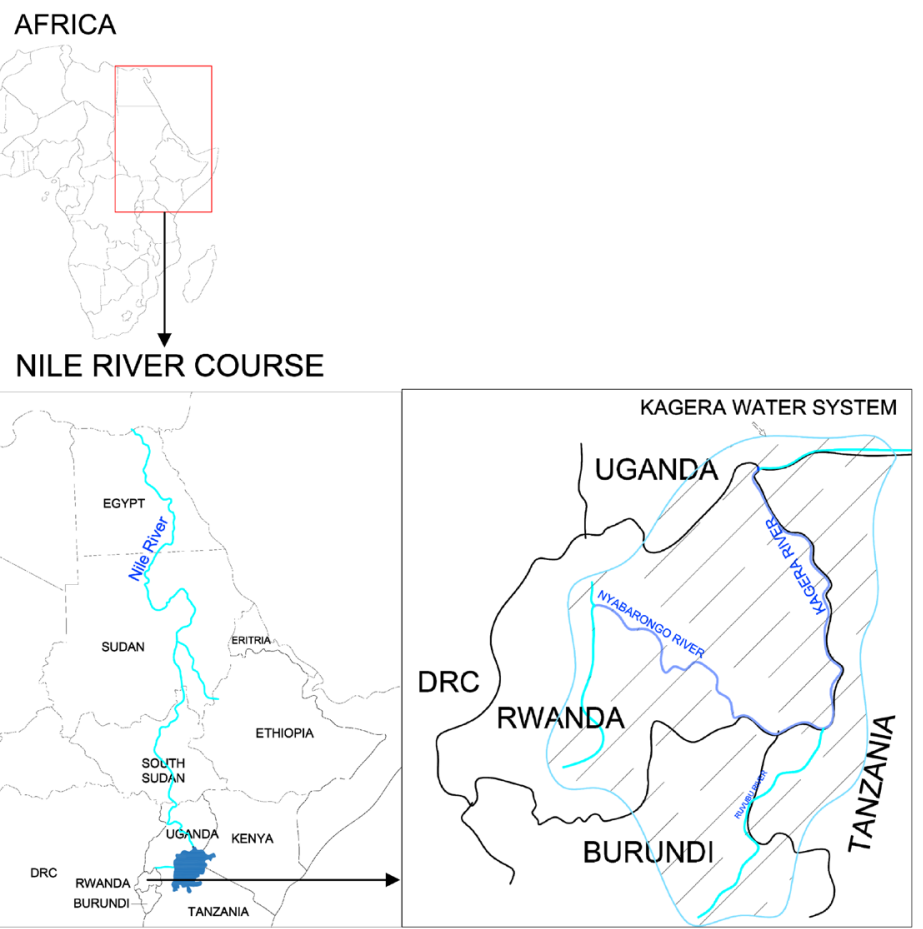

Figure 1. Kagera River Basin location.

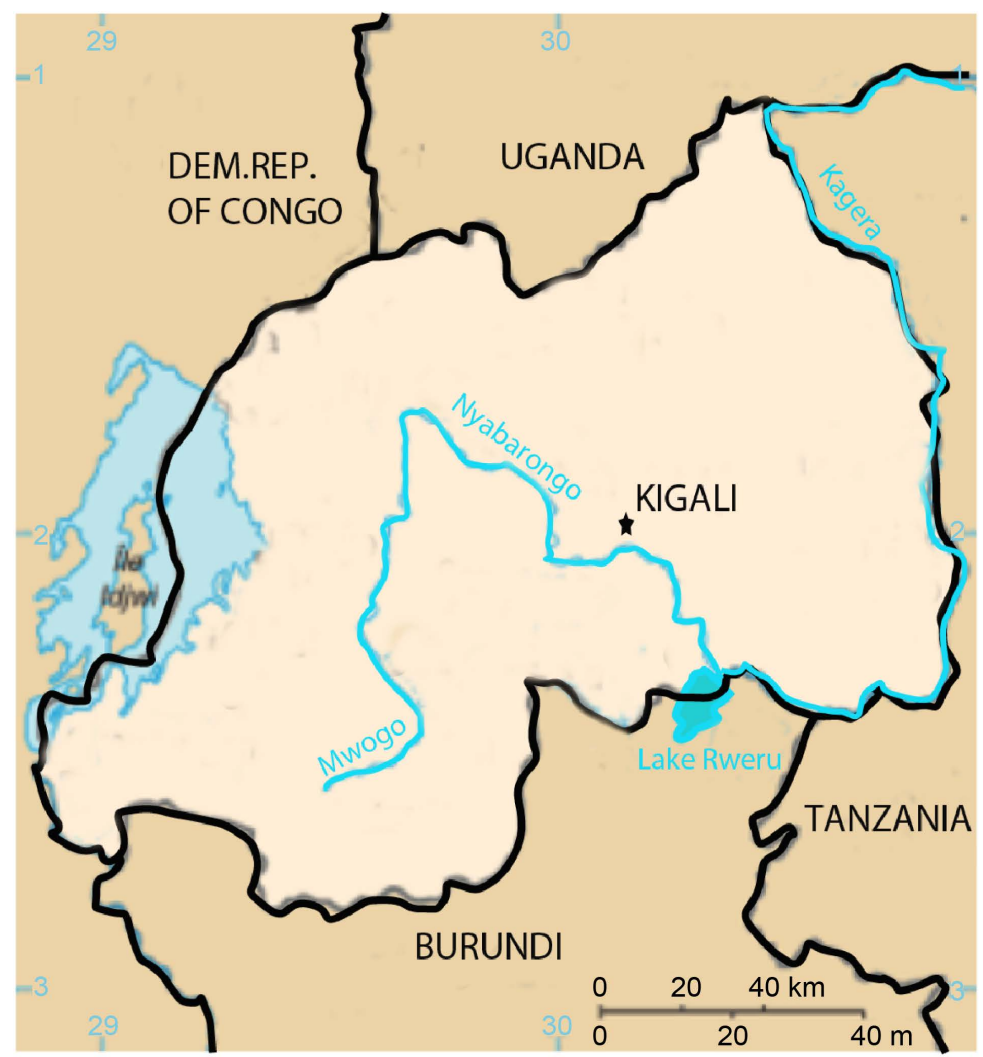

Figure 2. Map of Rwanda showing location of Nyabarongo River, which flows first north, then southeast past Kigali, then east along southeastern border of Rwanda. 
Table 1. Distribution of Kagera Basin in riparian countries.

\begin{tabular}{cccc}
\hline Country & Surface Area $\left(\mathbf{K m}^{\mathbf{2}}\right)$ & Total Area $\left(\mathbf{K m}^{\mathbf{2}}\right)$ & $\mathbf{\%}$ of Kagera River Basin \\
\hline Uganda & 241,000 & 5800 & 10 \\
Rwanda & 26,340 & 19,900 & 33 \\
Tanzania & 945,100 & 20,800 & 35 \\
Burundi & 27,834 & 13,300 & 22 \\
Total & $\mathbf{1 , 2 4 0 , 2 7 4}$ & $\mathbf{5 9 , 8 0 0}$ & $\mathbf{1 0 0}$ \\
\hline
\end{tabular}

Source: Kagera basin organisation development program, final report, 1982.

that flows from the highlands of Nyungwe National Park on the Congo-Nile Divide in Ruhengeri province along the border between Rwanda and Burundi until the junction with Nyabarongo at about $50 \mathrm{~km}$ south of Kigali after its turn to the mainland in Rwanda [7]. From that confluence, the Nyabarongo River flows eastwards through swampy valleys and small lakes in the lowlands of Bugesera-Gisaka in south-eastern Rwanda. From the Lake Rweru outlet, the Nyabarongo River changes the name to kagera and meanders through a swampy terrain for about $60 \mathrm{~km}$ and meets the Ruvubu River flowing through the Tanzanian uplands. Downstream the Kagitumba junction (which marks the border between Uganda and Tanzania), the Kagera changes direction and trends eastwards for $260 \mathrm{~km}$ to Lake Victoria.

\subsection{River Basin Management}

\subsubsection{Kagera Basin Organisation (KBO)}

Since 1971, numerous studies have been carried out in order to get a comprehensive development of the Kagera River Basin. In 1976, an Indicative Basin Plan provided a good Compendium of potentialities of the Kagera Basin. After many experts and officials missions throughout the basin, the four riparian countries took a political commitment to jointly exploit the water-based natural resources in order to develop their economies. Numerous conferences of donors and multidisciplinary studies were carried out and a Master Plan drawn up. The sectors of agriculture, energy, transport, communications and human resources development were chosen to be the priority sectors [8].

\subsubsection{The Nile Basin Initiative (NBI)}

The Nile River is one of the world's greatest assets running through 11 countries: Burundi, DRC, Egypt, Eritrea, Ethiopia, Kenya, Rwanda, South Sudan, The Sudan, Tanzania and Uganda. The region encompasses an area of 3 millions $\mathrm{km}^{2}$ and the countries of the Nile serve as a home for to an estimated 300 millions of people. The Nile River traverses $6700 \mathrm{~km}$ from its remotest source in the highlands of Burundi to the delta at the Mediterranean Sea in Egypt. As most other sub-Saharan African countries, the Nile riparian countries are facing poverty, political instability, rapid population growth, environmental degradation, to name but a few. From the economic perspective, the World Bank had characterized the Nile basin as a zone where "nothing flows". For the feasibility of the joint efforts to work together for the people of the Nile, the riparian governments established a cooperative framework called the "Nile Basin Initiative" with a demanding target of "achieving sustainable socioeconomic development through the equitable use of, and benefit from, the common Nile Basin water resources" [9].

\section{Water Resources Bulletin across Nyabarongo and Kagera River}

Rwanda has a dense hydrographic network. Lakes occupy an area of 128,190 ha; rivers cover an area of 7260 ha and water in wetlands and valleys a total of 77,000 ha. The country is divided into two major water basins, divided by a water divide line or ridge called Congo Nile Ridge. To the west of this line lies the Congo River Basin which covers $33 \%$ of the national territory and which receives $10 \%$ of the total national waters. To the East lies the Nile River Basin whose area covers $67 \%$ of the territory delivers $90 \%$ of the national waters. Waters of the Nile River Basin flow out the country through the Kagera River, the main tributary to Lake Victoria, which bears the outlet of the White Nile. Kagera River contributed 9\% to 10\% of the total Nile Waters [10]. Hydrological measurements are essential for the interpretation of water quality data and for water resource management. 
Variations in hydrological conditions have important effects on water quality. In rivers, such factors as the discharge (volume of water passing through a cross-section of the river in a unit of time), the velocity of flow, turbulence and depth will influence water quality [11]. The annual rainfall varies from $700-1400 \mathrm{~mm}$ in the East and lowlands of the West to $1200-1400 \mathrm{~mm}$ in the high altitude region. The temperature regime is more or less constant with a temperature regime of $16^{\circ} \mathrm{C}-17^{\circ} \mathrm{C}$ for high altitude region, $18^{\circ} \mathrm{C}-21^{\circ} \mathrm{C}$ for the central plateau region and $20^{\circ} \mathrm{C}-24^{\circ} \mathrm{C}$ for the eastern plateau and lowlands of the West. The climate is of the temperate equatorial continental type (AW3) according to KOPPEN classification. There are two rainfall seasons with the longer south-easterly monsoon rain between February and May, and the shorter north-easterly from September to November. The runoff responds to the rainfall with a higher peak in May and a smaller peak in November [12].

The upper tributaries are generally steep but include flatter reaches where swamps have formed. The average discharge is estimated to be $256 \mathrm{~m}^{3} / \mathrm{s}$ with a low flow of $85 \mathrm{~m}^{3} / \mathrm{s}$ at Kagera. Says that the Kagera is the main affluent of the Lake Victoria with a middle debit of $256 \mathrm{~m}^{3} / \mathrm{s}$ and has this title considered as the source of the Nil. One will note that has the entry of the Kagera in the Victoria lake, the debit of the Kagera is of $262 \mathrm{~m}^{3} / \mathrm{s}$. The main rivers in the Nile Basin of Rwanda are: Mwogo, Rukarara, Mukungwa, Base,Nyabarongo and the Akanyaru of which the water are drained by the Nyabarongo which becomes Kagera at the outlet of Rweru Lake [13].

\section{Water Use and Water Demand Projection}

The pressures on water resources primarily result from utilizing the natural resources to meet basic needs as well as social-economic development. The effects of water resources use are demonstrated in the changes in the quantity and quality of water. All aspects of human activities in Rwanda have produced varying impacts and degrees of modification to the available water resources and these impacts are manifest at the catchment and sub-catchment levels as the following examples illustrate.

\subsubsection{Domestic Water Use and Projected Water Demand}

The data from Energy and Water Sanitation Authority show that the water demand in Kigali city is $55,080 \mathrm{~m}^{3}$ per day, whereas nominal production is $30,525 \mathrm{~m}^{3}$ per day. This illustrates a deficit in the drinking water requirements for Kigali. It is estimated that water demand over the next decade will double in Kigali and rural areas and more than double for the semi-urban settlements. Table 2 shows the estimated consumption of water in 2005 and the projected water demand for 2020 based on Status, Trends and Key Issues in Water Resources Demand and population growth [14].

\subsubsection{Industrial Water and Agriculture Water Use}

The study on the Knowledge and Management of Water data done under the preparation of the National Management of the Water Resources Project [15] indicates that industrial water requirements will be between 300,000 and $900,000 \mathrm{~m}^{3} / \mathrm{yr}$ by 2020 in urban areas. Rwanda's economy is based on agriculture, and agriculture is rain-fed and is therefore exposed to vagaries of climate fluctuation. Many areas which use poor farming methods without integrating soil and water resources conservation tend to have weak agricultural productivity. In such instances, soil moisture becomes the limiting factor for crop growth. In 2000, the total national water withdrawal for agriculture was estimated at 150 million $\cdot \mathrm{m}^{3} /$ year and the share of agriculture estimated at $68 \%$. Rice growing (on $8500 \mathrm{ha}$ ) constituted the crop that used most irrigation at about 25,500,000 $\mathrm{m}^{3}$. The government is making efforts to promote irrigation including hillside irrigation, especially in the dry lands of the eastern province, to increase food security. This is in light of research that projects the agricultural water requirements for 2020. It shows that the eastern region will require more water than at present, while the Congo-Nile ridge region

Table 2. Potable water demand.

\begin{tabular}{ccc}
\hline Types of Settlements & Estimated Consumption (l/home/day) & Projected Needs for 2020 (I/home/day) \\
\hline Rural & 10 & 20 \\
Semi-Urban & 35 & 90 \\
Kigali & 48 & 90 \\
\hline
\end{tabular}


which will have enough rainfall will only require the development of rain harvesting systems to allow the utilization of water in drier seasons for food security purpose. Figure 3 shows the agricultural water requirements in 2020 [16].

\section{Cooperation and Regional Conflicts in River Basins}

\subsection{Cooperation and Water Conflict in the Literature}

The international nature of many of the world's great rivers and increasing scarcity of water has led to discussions in the academic literature of the growing potential for violent conflict, or "water wars", between nations over shared water resources [17] [18]. A related body of literature links environmental scarcity in broader terms with conflict [19]. The potential for security problems or violent conflict at an international or sub-national level has also been discussed in relation to the impacts of climate change and, more recently, in a special issue of Political Geography [20].

\subsection{Forms of Conflict and Cooperation}

The development of Water Event Intensity Scale [21], which draws from the International Cooperation and Conflict Scale. The scale ranges from extreme conflict at -7 , for a formal declaration of war, through to extreme cooperation at 7 for voluntary unification into one nation. In this scale, conflictive interactions include hostile verbal expressions (official or unofficial) and hostile diplomatic, economic or military acts. The same cases of conflicts also happen in Nile Basin.

\subsection{Current Conflicts and Treaties on Nile River}

The issue of Conflicts has never been far from the banks of the Nile. The same is true of most international waterways, but none to the degree of the Nile. The source in central Africa; its value to the 11 countries through which it flows and the total dependence of Egypt and Sudan on this life line have always made the political and biological life of the river a source of conflict, the Egyptians see the river as a gift from God to them. Without the Nile there would have been no Ancient Egypt and its great heritage, only desert. But Ethiopia, where most of the river's water originates, also wants to make use of it and has been planning a huge dam for years. On completion the Renaissance dam in 2017, costing $\$ 4.3$ billion and spanning the Blue Nile at the border with Sudan, is to generate 6000 megawatts of electricity. Ethiopia began to change the course of the river, displacing it by several hundred meters, in a move that has outraged Egypt and generated near panic over future water supplies. Egypt depends on the Nile for 98 per cent of its water and water is in increasingly short supply. The Arab world's

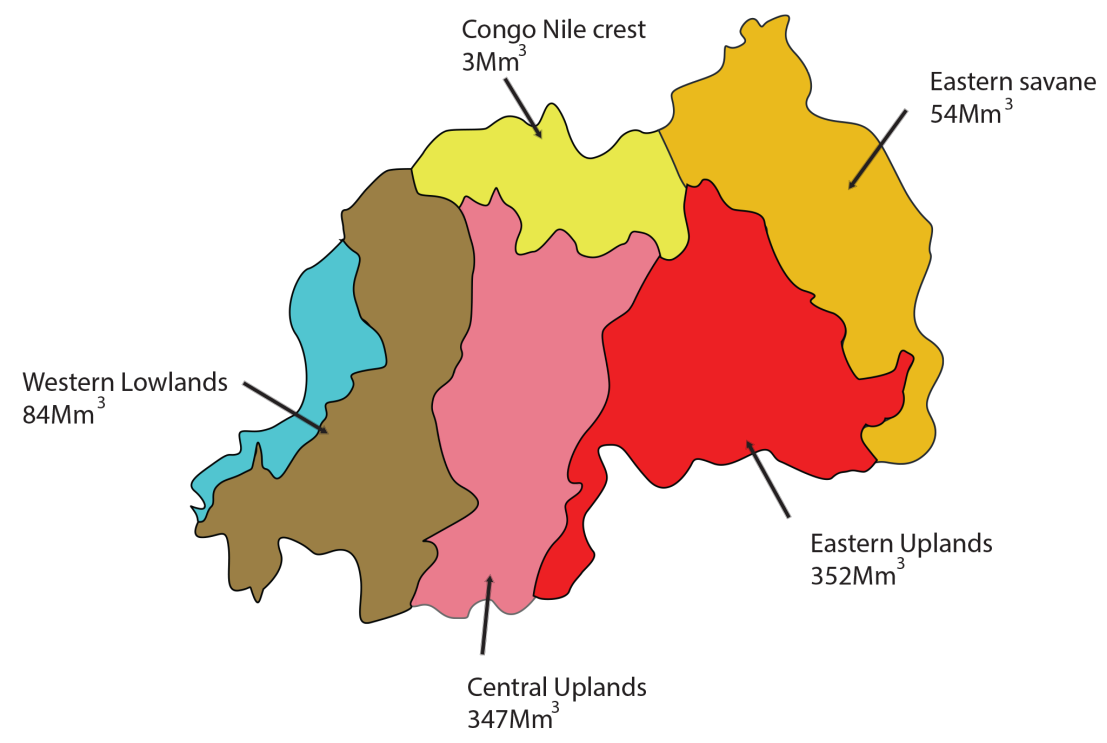

Figure 3. Water requirement in 2020 (million cubic meters) for agriculture in Rwanda. 
most populous country has seen its population soar from 53 million in 1990 to more than 80 million today.

Egypt is determined to uphold an agreement dating back to 1929 and the colonial era. This document provides for Egypt and Sudan to have rights to more than 80 per cent of the water, even though the Nile flows through 11 countries in all. The other countries aim to change this provision. Ethiopia's parliament has now passed the ratification of a treaty intended to replace the old Nile Water Agreement, in terms of which a joint forum will decide on how the waters are used. But Egypt has rejected this, insisting on its prior rights, in the longer term, Egypt will have to make concessions to Addis Ababa as Ethiopia wants to solve this by diplomatic negotiations [22].

\subsection{Benefits, Conditions and Limitations of Cooperation}

International river basins cooperation is seen as desirable [23] describe four types of benefits: firstly, benefits to the river from cooperative basin-wide environmental management, such as improvements in water quality and maintenance of biodiversity; and secondly, benefits from the river, such as hydropower, irrigation, flood and drought management and navigation. Thirdly, they hypothesize benefits because of the river, for example reduced risk of conflict between riparian nations and increased food and energy security, and fourthly, benefits beyond the river, such as integration of regional infrastructure, markets and trade. Sadoff and Grey suggest that there are costs to non-cooperation, as well as to cooperation and that, depending on the particular circumstance, the scale of benefits may or may not outweigh the costs of cooperation. In the absence of strong cooperation, [24] assert that the varying intensities of conflict that commonly exist, but fall short of violent conflict, nevertheless have negative consequences on the less powerful riparian countries. It is clear that all riparian countries of Nile Basin should cooperate each other to avoid any kind of water war.

\section{Conclusions}

Even though Rwanda is well reported in water resources management progress; the country faces a number of problems in relation to the sustainable management and protection of these resources, which will ultimately, if not adequately and timely addressed, detrimentally affect the country's economic and social development. The provision of an enabling environment within which sustainable water resources management can be achieved includes the preparation of a comprehensive National Water resources management policy, the promulgation of legislation and appropriate regulations which will allow the implementation of the policy, and the establishment of a rational institutional framework through which all government levels can function. Therefore, the following issues need to be addressed:

1) Frequent assessment and monitoring of water resources including the collection, analysis, storage and dissemination of water related information; availability of reliable data is necessary to help governments in appropriate decision making.

2) Capacity building to enhance managerial and technical skills within water resources sector.

3) The protection of critical environmental functions to ensure the sustainability of the source of water resources, conflicts in the region affecting effective participation of countries and time implementation of projects.

4) Broadening participation at the country level-through projects and multiplier effect, and other activities including partnership for watershed management.

5) Increase country contribution and financial sustainability of the institution; strengthening Linkages of national and regional initiatives and programs.

6) Institutional arrangements at country level for improving data collection and management, government to invest in water and related resources monitoring and effectively share data.

However, to deal with challenges for water resource development and management in the Nil Basin there should be a transitional institutional mechanism for co-operation, an agreed vision and basin-wide framework, and a process to facilitate substantial investment in the Nile basin. It is based on the recognition that the basin has a shared past and a shared future, and that there is an urgent need for development and for the alleviation of poverty. It represents deep commitment by the Nile riparian countries to foster co-operation and pursue jointly the sustainable development and management of Nile water resources for the benefit of all.

\section{Acknowledgements}

This study is supported by the National Science Fund of China (No.41272249), Research Fund for the Doctoral Program of Higher Education of China (No.20110072110020). 


\section{Conflict of Interest}

The authors declare that they have no conflict of interest.

\section{References}

[1] CGIS-UNR. Environment and Poverty (2003) A Pilot Study on the Relationship between Environment and Poverty Mapping. UNDP, Kigali.

[2] MINALOC (2003) The Draft of National Policy for the Management of Risks and Disasters in Rwanda.

[3] MINAGRI (1998) National Policy for the Management of Water Resources.

[4] NISR (2012) Rwanda Census. The National Institute of Statistics of Rwanda. Kigali, Rwanda.

[5] Nzeyimana, L. (2003) Rusumo Dam-Social Challenge in Kagera River Basin: Participation of the Affected Population. Linköping University, Sweden.

[6] Ndayiragije, D. (1992) A Geomorphological Study of the Kagera Basin. Unesco/University of Burundi, Bujumbura.

[7] Twagiramungu, F. (2006) Environmental Profile of Rwanda. National Authorizing Office of FED and European Commission.

[8] NELSAP (2001) 11-12 December Report from NELSAP River Basin Project Preparatory Workshop. Nile Basin Initiative.

[9] NBI (2001) Water Resources Planning and Management, Project Document. Nile Basin Initiative.

[10] NBI (2001) Transboundary Environmental Analysis. Nile Basin Initiative.

[11] Ndege (1996) Strain, Water Demand, and Supply Directions in the Most Stressed Water. Civil Engineering Department, University of Nairobi, Nairobi.

[12] NBI (2005) National Nile Basin Water Quality Monitoring Report for Rwanda. Nile Transboundary Environmental Action Project, Nile Basin Initiative.

[13] RNRA (2012) Water Resources Information Bulletin for June-July 2012. Rwanda National Resources Authority, Kigali.

[14] MINITERE (2005) Project of National Management of Water Resources. Components D: Technical Studies. The Ministry of Lands, Environment, Forestry, Water and Mines.

[15] PGNRE (2005) Knowledge and Data Management on Water in Rwanda. General Technical Report, Kigali.

[16] K.V.P. (2006) Analysis on the Integrated Management of Water Resources in Rwanda. Working Paper for the NGO Protos, Final Report.

[17] Toset, H.P.W., Gledisch, N.P. and Hegre, H. (2000) Shared Rivers and Interstate Conflict. Political Geography, 19, 971-996. http://dx.doi.org/10.1016/S0962-6298(00)00038-X

[18] Gleditsch, N.P., Furlong, K., Hegre, H., Lacina, B. and Owen, T. (2006) Conflicts over Shared Rivers: Resource Scarcity or Fuzzy Boundaries? Political Geography, 25, 361-382. http://dx.doi.org/10.1016/j.polgeo.2006.02.004

[19] Ronnfeldt, C.F. (1997) Three Generations of Environmental Research. Journal of Peace Research, 34, 473-482. http://dx.doi.org/10.1177/0022343397034004009

[20] Nordås, R. and Gleditsch, N.P. (2007) Special Issue on Climate Change and Conflict. Political Geography, 26, 627736. http://dx.doi.org/10.1016/j.polgeo.2007.06.003

[21] Wolf, A.T., Yoffe, S.B. and Giordano, M. (2003) International Waters: Identifying Basins at Risk. Water Policy, 5, 2960.

[22] Dudin, M. and Frentzen, C. (2015) Egypt-Ethiopia Conflict over Nile Waters Flares. http://www.rappler.com/world/31553-egypt-ethiopia-conflict-over-nile-waters-flares

[23] Sadoff, C.W. and Grey, D. (2002) Beyond the Rivers: The Benefits of Cooperation on International Rivers. Water Policy, 4, 389-403. http://dx.doi.org/10.1016/S1366-7017(02)00035-1

[24] Zeitoun, M. and Mirumachi, N. (2008) Transboundary Water Interaction: Reconsidering Conflict and Cooperation. International Environmental Agreements, 8, 297-316. http://dx.doi.org/10.1007/s10784-008-9083-5 